УДК 681.513

(C) О.О. Броварець, к.т.н.

Київський кооперативний інститут бізнесу і права

\title{
МЕТОДИКА РОЗРАХУНКУ ПИТОМОЇ ЕЛЕКТРОПРОВІДНОСТІ АГРОБІОЛОГІЧНОГО ҐРУНТОВОГО СЕРЕДОВИЩА СТАЦІОНАРНИМ КОНТАКТНИМ МЕТОДОМ
}

Сучасне землеробство передбачає виконання певної технологічної операиії, згідно відповідної картограми-завдання, яка розроблясться попередньо на основі різнопланової інформачії. Знання певної структура варіабельності грунтового покриву, отриманих з використанням інформачійно-технічних систем локального оперативного моніторингу агробіологічного стану сільськогосподарських угідь, дозволяе прийняти ефективні оперативні рішення для ефективного управління агробіологічним потенціалом сільськогосподарських угідь.

Очевидно, щзо за таких умов виникає необхідність у принципово нових підходах до ведення агропромислового виробництва, щуо полягає у забезпеченні належної якості виконання 
технологічних операцій. Якість виконання технологічних операцій $\epsilon$ інтегральним показником ефективності виробництва сільськогосподарської продукиії в межах агробіологічного поля. Необхідна якість виконання основних технологічних процесів у рослинництві забезпечується за рахунок інтегрованих інформаційно-технічних систем оперативного моніторингу агробіологічного стану сільськогосподарських угідь.

Це відкриває нові перспективи до ведення органічного землеробства з використанням таких «розумних» сільськогосподарських машин.

У зв'язку, з ции ставиться завдання отримання достовірних даних про агробіологічний стан грунтового середовища шляхом зменшення похибки при визначенні величини електропровідних властивостей трунту, забезпечення індивідуальної стабілізачіі робочих електродів та механізму піднімання/опускання робочих електродів, копіювання нерівностей грунтового середовища, зменшення інтенсивності руйнування структури трунту, самоочищення робочого контакту електроду $i$ забезпечення стабільності електричного контакту електрода з трунтом, шляхом удосконалення конструкиії приладу. Поставлене завдання досягається иляхом використання інформачійно-технічноі системи оперативного моніторингу стану трунтового середовища конструкиї для визначення електропровідних характеристик грунтового середовища.

Мета даного дослідження $\epsilon$ визначення критичного навантаження при втраті стійкості тонкостінними робочими електродами виконаними у вигляді робочих електродів різноі форми (тонкостінних суцільних, трьохспицевих та чьотирьохспищевих дисків з різною товщиною ободу) інформачійнотехнічної системи локального-оперативного моніторингу агробіологічного стану грунтового середовища різної конфігурачиї при однобічному стисканні.

\section{ІНФОРМАЦІЙНО-ТЕХНІЧНА СИСТЕМА, ЛОКАЛЬНИЙ ОПЕРАТИВНИЙ МОНТТОРИНГ, ГРУНТ, ПРОБИ, ВАРІАБЕЛЬНІСТЬ, ВЕЛИЧИНА, ДОСЛІДЖЕННЯ}

Постановка проблеми. Один 3 головних підходів при застосуванні технологій точного землеробства - оптимізувати урожайність і забезпечити екологічну якість сільськогосподарської продукції із врахуванням зон управління сільськогосподарським полем. У цьому аспекті важливу роль відіграє визначення грунтової електричної провідності для визначення величини прибутку на основі даних просторової мінливості та вмісту поживних речовин у 
грунті. Знання певної структура варіабельності грунтового покриву дозволяє прийняти ефективні рішення для управління агробіологічним потенціалом сільськогосподарських угідь [1].

Огляд сучасних літературних джерел та наукових розробок [1] показує, що останніми роками відбувається процес інтеграції натурального (органічного, або біологічного), біодинамічного, екстенсивного, інтенсивного (промислового) та no-till землеробства 3 новітніми технологіями, зокрема 3 інформаційно-технічними системами локального оперативного моніторингу стану сільськогосподарських угідь. При цьому останній напрям $\epsilon$ найбільш актуальним та перспективним для умов України.

Сучасне сільськогосподарське виробництво передбачає широке використання автоматизованих систем для моніторингу стану сільськогосподарських угідь.

Втілення сучасних технологій землеробства дозволяє планувати витрати насіннєвого матеріалу, добрив, пестицидів та інших технологічних матеріалів, у тому числі палива, визначати загальну стратегію управління агробіологічним потенціалом поля тощо. Проте, на сьогодні при реалізації даних технологій бракує ефективних систем збору та реєстрації (моніторингу) місцевизначеної інформації (агробіологічної та фітосанітарної) про стан сільськогосподарських угідь у технологіях точного землеробства. Існуючі способи і засоби реалізації цього процесу недосконалі [2, 3, 4].

У цьому сенсі набуває актуальності розробка та використання принципово нового класу сільськогосподарських машин інформаційно-технічних систем локального оперативного моніторингу агробіологічного стану сільськогосподарських угідь.

У зв'язку із цим важливим завданням $є$ розробка $\mathrm{i}$ обгрунтування сучасної інформаційно-технічної системи локального оперативного моніторингу агробіологічного стану сільськогосподарських угідь.

Аналіз останніх досліджень і публікацій. Структура грунту змінюється в значних межах на багатьох сільськогосподарських полях. Фізичні властивості грунту, як наприклад грунтова структура, мають прямий ефект на водомісткість, ємність катіонного обміну, урожайність тощо. Поживні речовини, що містяться у грунтах, використовуються рослиною і ї вміст у грунті зменшуються. Загальноприйнятою характеристикою вмісту поживних речовин у грунтів $є$ вміст азоту, наявність якого у грунті значною мірою визначає урожайність. 
Картографія грунтової електричної провідності, широко використовується як ефективний засіб відображення грунтової структури i інших грунтових властивостей [5]. Швидкий опис мінливості сільськогосподарських угідь - важливий компонент для зональних методів управління [6].

Ця варіативність занадто важлива, щоб іiі ігнорувати, i повинна враховуватися при відборі проб (рис. 1).

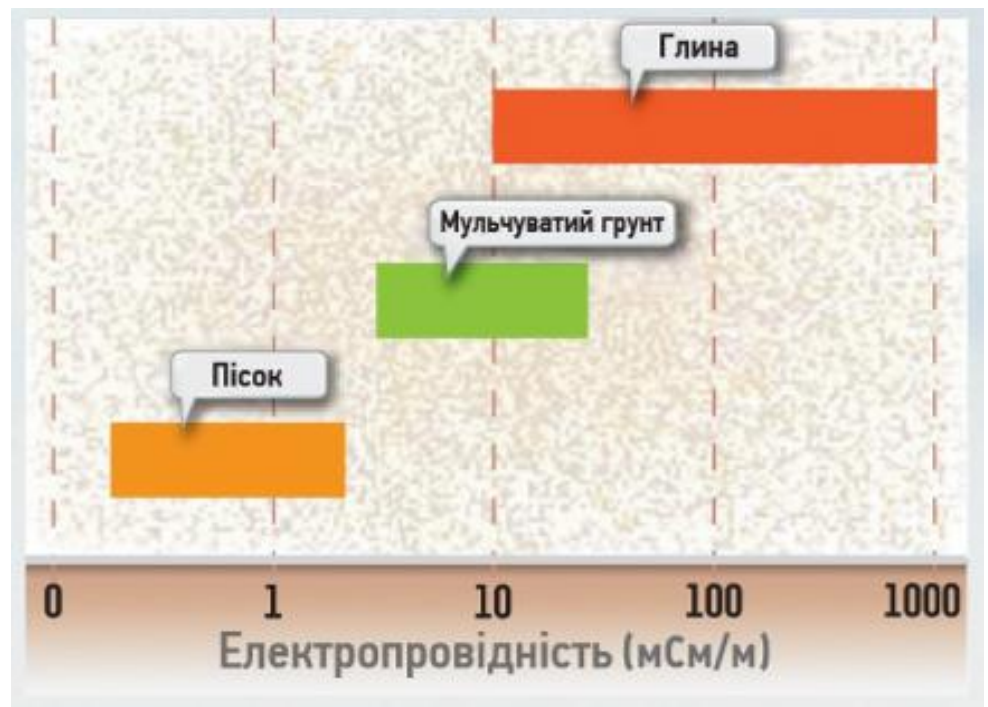

Рис. 1 - Електропровідність грунту

Карти грунтової електропровідності дають можливість отримати картограми:

- Змінних норм внесення технологічного матеріалу (насіння і мінеральних добрив) на основі очікуваної врожайності по кожній окремій ділянці, розраховані виходячи 3 величини електропровідності.

- Змінні норми внесення насіння на основі даних про глибину верхнього (орного) шару грунту.

- Змінні норми внесення в грунт гербіцидів на основі даних про органічні речовини, структуру грунту і електропровідності.

- Змінні норми внесення вапна на основі даних про агробіологічний стан грунтового середовища відповідно до рівнів електропровідності. 
Для картографування грунту приладом EC Veris 3100 використовується позашляховик, який оснащено бортовим комп'ютером 3 технологією паралельного водіння, GPS-приймачем, (рис. 2) та причіпним агрегатом з дисками (з розміщеними в дискамиелектродами). При проведенні вимірювань, агрегат рухається по полю із зануреними в грунт дисками на глибину 2-5 см, одна пара ізольованих електродів вводить електричний струм у грунт, інші електроди вимірюють струм, що змінюється в залежності від опору грунту[4].
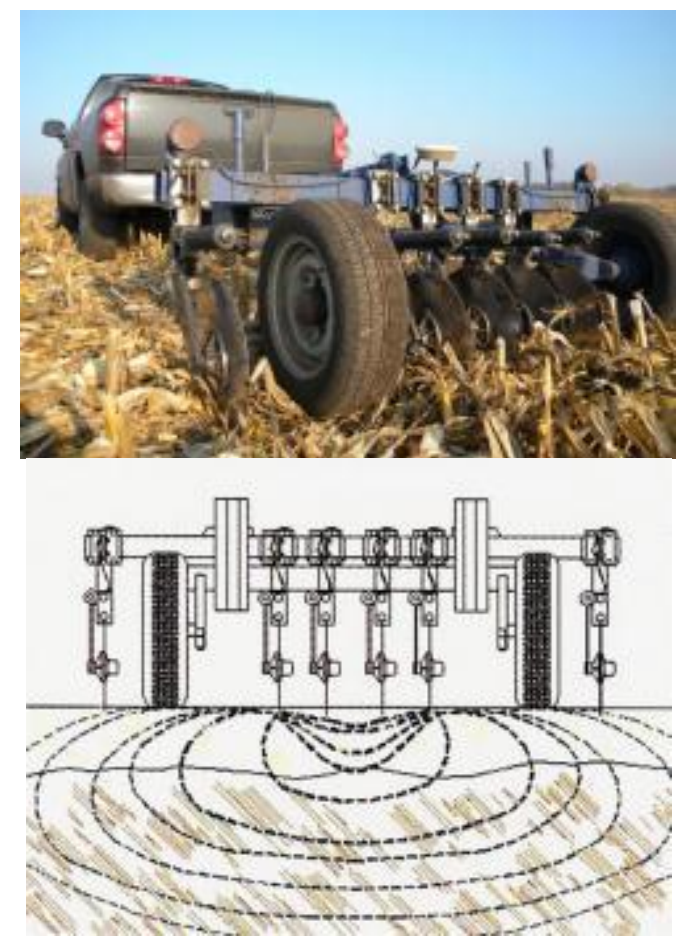

Рис. 2 - Пристрій ЕС Veris 3100

Причіпний агрегат Veris тягнеться по полю, одна пара ізольованих електродів вводить електрострум в грунт, а інша пара вимірює падіння напруги, яка буде відрізнятися - так наприклад, глина проводить струм краще, ніж мул або пісок. Заміри електропровідності поєднуються 3 даними GPS i наочно відображаються у вигляді карти. Veris 3100 використовує два промені електропровідності для картографування двох глибин грунтів (0-30,5 см і 0-91,5 см) одночасно. 
Veris 3100 формує два набори карт - карту поверхневого шару (30,5 см) і карту захоплюючу кореневу зону $(91,5$ см). Карта верхнього шару часто використовується для вибору місць забору проб, а більш глибока карта - для визначення норми внесення добрив (особливо азотних) [5].

Дані пристрої надто вартісні та дають значну похибку при вимірюваннях, це створю умови для подальшого дослідження даних систем.

Метою дослідження є розробка ефективної інформаційнотехнічної системи оперативного моніторингу стану сільськогосподарських угідь конструкції Олександра Броварця.

Результати дослідження. Електропровідність (soil conductivity) - це властивість матеріалу передавати (проводити) електричний струм, вимірювана в сименсах на метр $(\mathrm{Cm} / \mathrm{M})$ або в миллисименсах на метр (мСм/м).

Інформаційно-технічна система оперативного моніторингу стану грунтового середовища конструкції Олександра Броварця пристрій для визначення електропровідних властивостей грунтового середовища конструкції Олександра Броварця може працювати з ручними пристроями, розміщуватися на транспортних засобах високої прохідності, розміщуватися на сільськогосподарських та енергетичних засобах, які виконують технологічну операцію, що дозволяе отримувати оперативні дані про агробіологічний стан грунтового середовища та приймати оперативні рішення щодо керування нормою внесення технологічного матеріалу (насіння, мінеральних добрив тощо).

Всі раніше декларовані елементи таких технологій точного (керованого) землеробства (лабораторний аналіз (одна проба на 510 га), урожайність) не давали можливості забезпечити такий точний підхід. Ця система дає можливість отримати достовірну інформацію про агробіологічний стан грунтового середовища із кожного квадратного метра сільськогосподарського поля.

Такої точності до сих пір не мають жодні представлені на ринку технології починаючи від лабораторного обстеження (одна проба на 5-10 га) і закінчуючи супутниковим моніторингом (точність до $10 \mathrm{~m}^{2}$ ). Крім того необхідно враховувати вартість даних технологій, оскільки собівартість однієї проби коливається в межах 1-10 \$, супутникового моніторингу - від 20 \$, у той час коли вартість такої проби з використання запропонованої конструкції технічної системи оперативного моніторингу складає менше $0,1 \$$ за м² (табл. 1 ). 
Таблиця 1 - Методи моніторингу агробіологічного стану грунтового середовища сільськогосподарських угідь

\begin{tabular}{|c|c|c|c|c|c|}
\hline $\begin{array}{c}\text { № } \\
\Pi / \Pi\end{array}$ & $\begin{array}{c}\text { Метод } \\
\text { моніторингу } \\
\text { стану } \\
\text { агробіологічного } \\
\text { стану }\end{array}$ & $\begin{array}{c}\text { Щільність } \\
\text { відбору } \\
\text { проб } \\
\text { грунту на } \\
100 \text { га }\end{array}$ & $\begin{array}{c}\text { Розмір } \\
\text { ділянки з } \\
\text { якої } \\
\text { проводитьс } \\
\text { я забір, м² }\end{array}$ & $\begin{array}{l}\text { Вартість } \\
\text { однієї } \\
\text { проби } \\
\text { (знімку), } \\
\text { \$, ум. од. }\end{array}$ & $\begin{array}{l}\text { Вартість } \\
\text { проби } \\
\text { (знімку) } \\
\text { на } 100 \\
\text { га, \$, ум. } \\
\text { од. }\end{array}$ \\
\hline 1 & $\begin{array}{l}\text { Лабораторний } \\
\text { метод }\end{array}$ & $10-15$ & $\begin{array}{c}10000^{*} \\
1000\end{array}$ & $1-10$ & $\begin{array}{l}100- \\
1000\end{array}$ \\
\hline 2 & $\begin{array}{l}\text { Супутниковий } \\
\text { моніторинг }\end{array}$ & \begin{tabular}{|c|}
1 знімок \\
роздільною \\
здатністю \\
до $10 \mathrm{M}$ \\
\end{tabular} & $100 * 100$ & $10-100$ & $\begin{array}{l}100- \\
1000\end{array}$ \\
\hline 3 & $\begin{array}{l}\text { Технічна } \\
\text { система } \\
\text { оперативного } \\
\text { моніторингу } \\
\text { стану } \\
\text { сільськогоспода } \\
\text { рських угідь } \\
\end{array}$ & 1000 & $10 * 10$ & 0,1 & 100 \\
\hline 4 & $\begin{array}{l}\text { Технічна } \\
\text { система } \\
\text { оперативного } \\
\text { моніторингу } \\
\text { стану } \\
\text { сільськогоспода } \\
\text { рських угідь }\end{array}$ & 10000 & $1 * 1$ & 0,1 & 1000 \\
\hline
\end{tabular}

Пристрій для визначення електропровідних властивостей грунтового середовища дає можливість оперативно визначити параметри агробіологічного стану грунтового середовища, забезпечити «індивідуальний» підхід до кожної елементарної ділянки поля 3 використанням даних електропровідних властивостей грунтового середовища (рис. 3). 


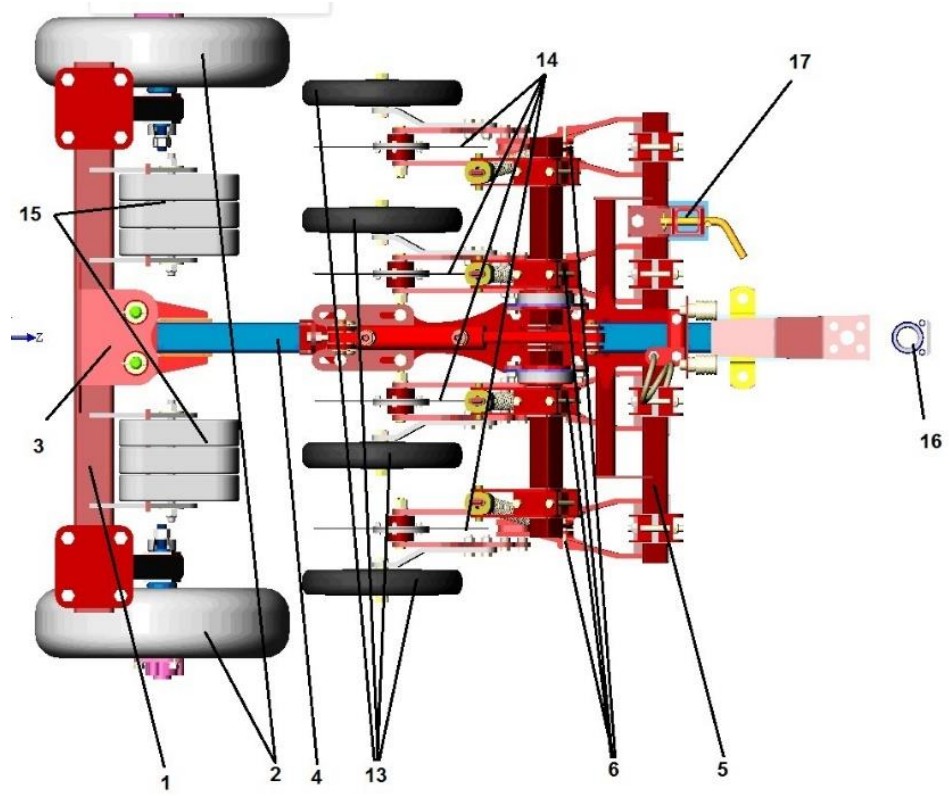

Рис. 3 - Загальний вигляд інфрмаційно-технічної системи локального оперативного моніторингу стану грунтового середовища

Пристрій для визначення електропровідних властивостей грунтового середовища використовують: перед виконанням технологічної операції, одночасно 3 виконанням технологічної операції (сівба, внесення мінеральних добрив тощо); протягом вегетації та після збирання врожаю.

Це відкриває нові перспективи до ведення органічного землеробства 3 використанням таких «розумних» сільськогосподарських машин.

На рис. 3 - зображено загальний вигляд технічної системи оперативного моніторингу стану грунтового середовища конструкції Олександра Броварця (вид зверху), рис. 4 - зображено загальний вигляд технічної системи оперативного моніторингу стану грунтового середовища конструкції Олександра Броварця (вид збоку).

Таке технологічне рішення дасть можливість забезпечити оптимальне керування нормою висіву технологічного матеріалу 
(насіння, добрива тощо) із врахуванням агробіологічного стану грунтового середовища.

Технічна система оперативного моніторингу стану грунтового середовища конструкції Олександра Броварця складається (рис. 4) з опорних коліс 1, П-подібної рами 2, кріплення 3 , повздовжньої рами 4, поперечної рами 5, шарнірів 6 , важелів 7 , стояків-пружин 8 , кронштейну 9 , обертового валу 10 , гідроциліндру 11 , кронштейну кріплення 12 , копіювальних коліс 13 , робочих електродів 14, баласту 15, фаркопу 16 та підставка 17.

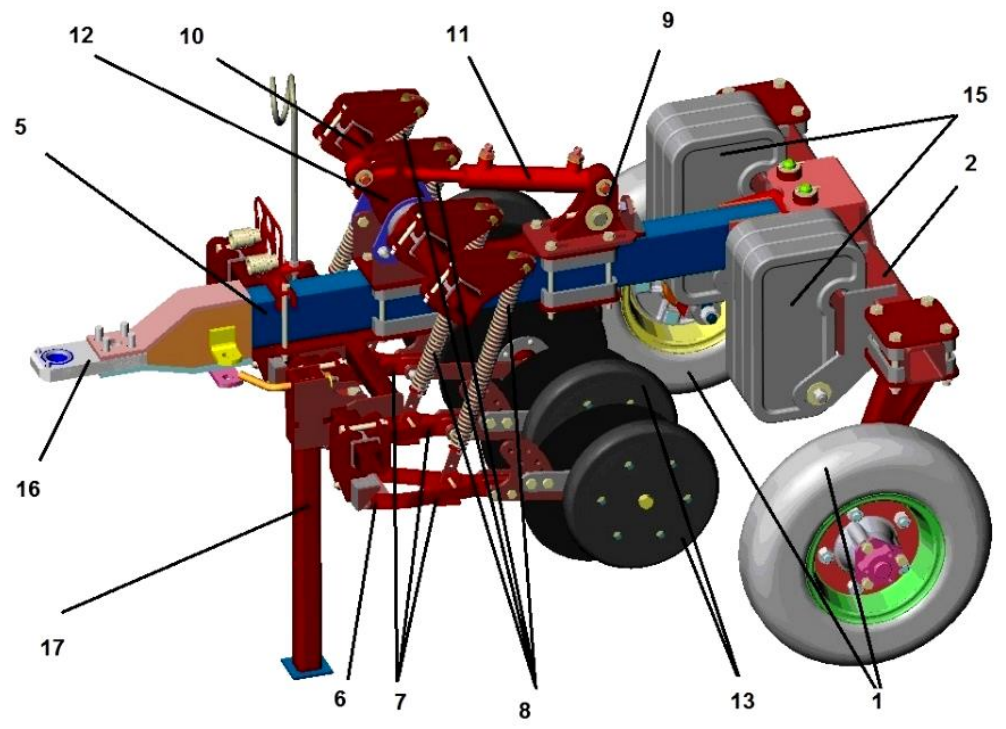

Рис. 4 - Загальний вигляд інформаційно-технічної системи локального оперативного моніторингу агробіологічного стану грунтового середовища

При використанні такого пристрою є значна похибка при визначенні, яка обумовлена тим, що під час виконання робочого процесу порушується стабільність контакту диска-електрода 3 грунтом, що викликано поперечними відхиленнями робочих дисківелектродів відносно прямолінійного напрямку руху, обумовленого конструкцією пристрою, відсутністю копіювання нерівностей поверхні поля дисками-електродами. При цьому змінюється площа контакту диска-електрода 3 грунтом, оскільки при поперечних 
коливаннях плоскі диски-електроди однією стороною можуть взагалі не контактувати із грунтом.

Важливим параметром при вимірюванні електропровідних характеристик грунтового середовища $\epsilon$ забезпечення стабільної площі контакту робочих електродів з грунтом. Наявні конструкції не повністю виконують зазначені умови, що негативно впливає на достовірність отриманої інформації. У зв'язку з цим виникла необхідність у розробці конструкції, яка б забезпечувала стабільність робочих електродів 3 грунтом під час вимірювання електропровідних властивостей грунтового середовища.

Для унаочнення недоліків наявної конструкції та переваг розробленої конструкції подано їхні схеми на рис. 5.1, рис. 5.2, рис. 6.

Варто сказати, що наявна і розроблена (рис. 5.1, рис. 5.2, рис. 6) конструкція систем має ряд спільних елементів, зокрема спільними елементами є: 1 опорне колесо, 2 рама, 3 робочий електрод. Далі наявна система містить 4 стояк, який жорстко з'єднаний з рамою, тому при русі сільськогосподарськими угіддями така система може утворювати борозни шириною $h$, внаслідок виникнення кутів крену, деференту та рискання, зумовлених не прямолінійним рухом агрегатів, внаслідок їхнього відхилення або поворотів. У свою чергу, це сприяє виникненню похибок вимірювання електропровідних параметрів грунтового середовища, оскільки одна сторона диску взагалі не контактує 3 грунтом (рис. 5.2, а).

У розробленій конструкції така проблема виключена внаслідок компенсації таких кутів частково за рахунок підвіски, а частково - верхніми та нижніми шарнірами підвіски розробленої конструкції, які дозволяють компенсувати поперечне відхилення $\alpha$ у межах 15-20 градусів, при цьому забезпечити стабільний контакт електродів 3 грунтом. 3 використанням копіювальних коліс 6 (рис. 4.1, 4.2, рис. 5) у наявній конструкції чітко забезпечується глибина $H$ руху робочих електродів у грунті. У наявній конструкції (рис. 4.1, рис. 4.2., рис. 5.) вона змінюється внаслідок кутів деференту, обумовлених коливанням та поперечним переміщенням конструкції системи під час руху нерівностями поверхні поля. 

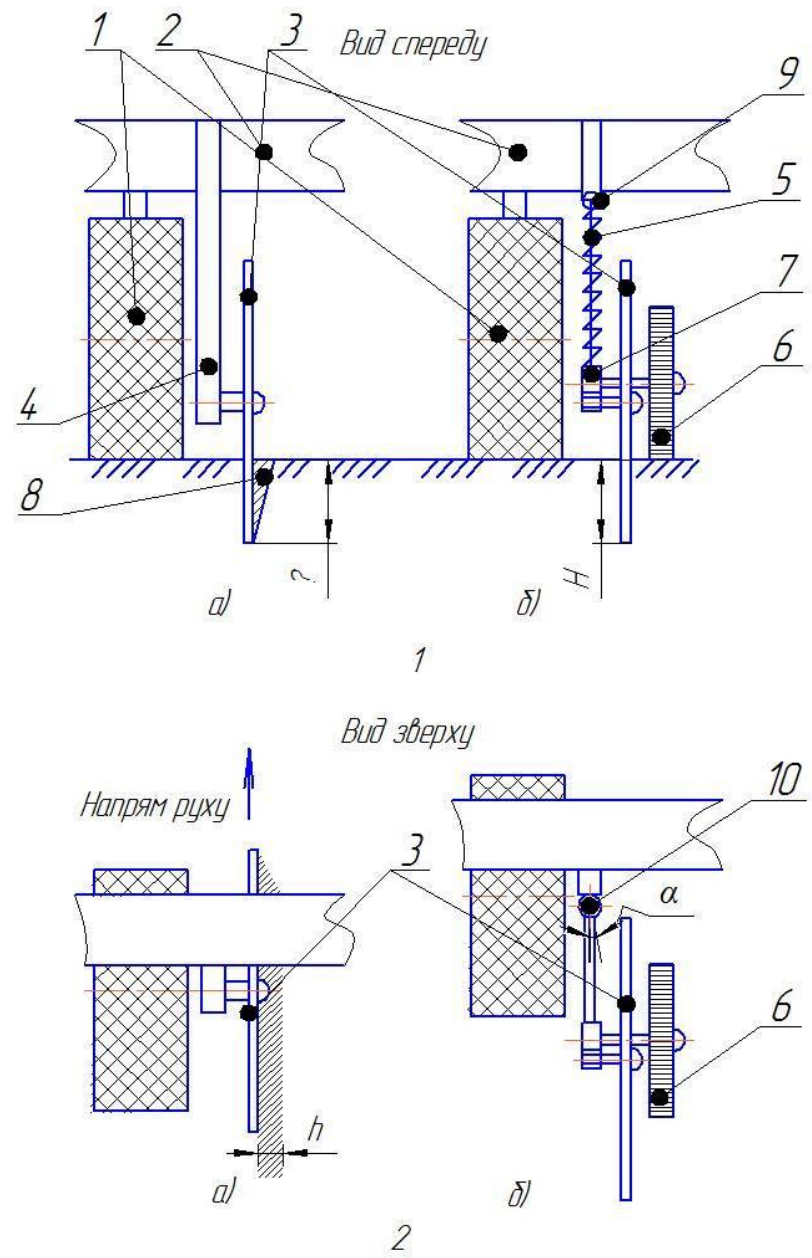

Рис. 5 - Порівняльна схема пристрою для визначення електропровідних характеристик грунтового середовища (вид спереду, вид зверху):

а) наявна конструкція; б) розроблена конструкція;

1 - опорне колесо; 2 - рама; 3 - робочий електрод; 4 - стойка;

5 - вертикальна стійка підвіски; 6 - копіювальне колесо;

7 - регулювальний механізм глибини колеса; 8 - утворена робочим електродом борозна; 9 - верхній шарнір; 10 - нижній шарнір. 


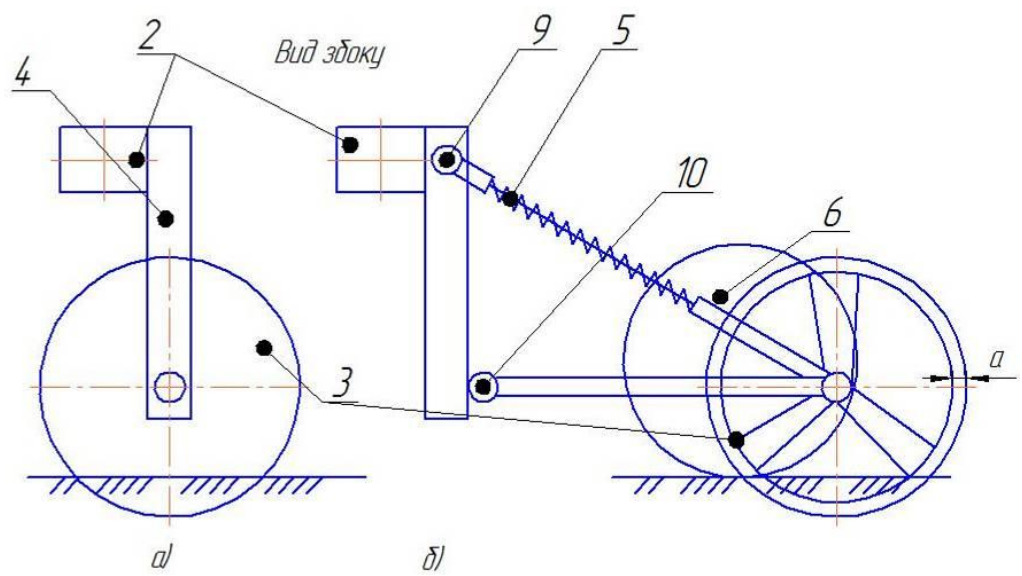

Рис. 6 - Порівняльна схема пристрою для визначення електропровідних характеристик грунтового середовища (вид збоку): а) наявна конструкція; б) розроблена конструкція;

2 - рама; 3 - робочий електрод; 4 - стойка; 6 - опорне колесо; 5 вертикальна стійка підвіски; 9 - верхній шарнір;

10 - нижній шарнір.

Загальними принциповими відмінностями інформаційнотехнічної системи локального оперативного моніторингу агробіологічного стану грунтового середовища - пристрою для визначення електропровідних властивостей грунтового середовища є:

1. Наявність копіювального колеса, яке визначає глибину ходу робочого електроду в грунті $H$.

2. Підвіска опорного колеса та робочих електродів.

3. Трьохспицевий тонкостінний металевий диск з ободом для забезпечення стабільної площі контакту електродів з грунтом.

4. Шарнірне розміщення важільної підвіски робочих електродів 3 грунтом для компенсації кутів крену, деференту та рискання, обумовлених рухом машинно-тракторного агрегату інформаційно-технічною системою оперативного моніторингу агробіологічного стану грунтового середовища конструкції Олександра Броварця та забезпечення стабільного контакту робочих електродів з грунтом. 
Метод розрахунку питомої електропровідності грунту ( $\rho$ ) стаціонарним контактним методом.

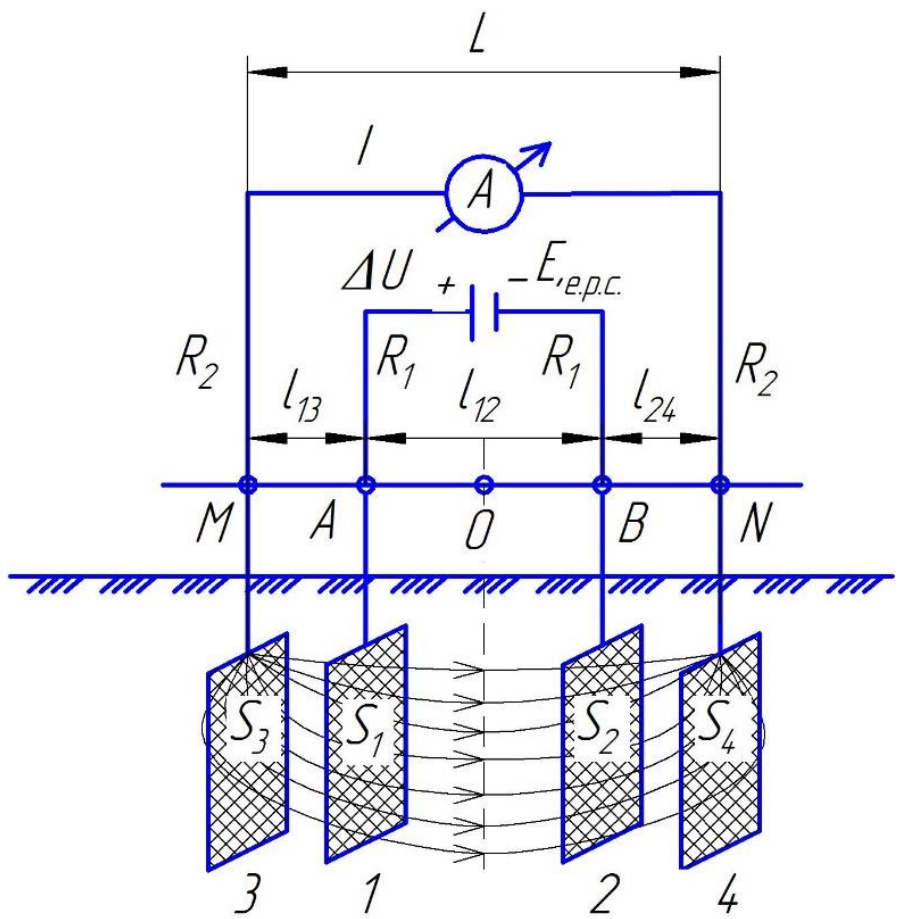

Рис. 5 - Розрахункова схема вимірювання питомої електропровідності грунтового середовища сільськогосподарських угідь 3 використанням

інформаційно-технічної системи локального оперативного моніторингу агробіологічного стану сільськогосподарських угідь грунтового середовища

Технічний результат, який досягається 3 використанням інформаційно-технічної системи локального оперативного моніторингу агробіологічного стану грунтового є:

1. Забезпечення стабільного контакту електродів з грунтом: внаслідок компенсації кутів крену, деференту та рискання, обумовлених рухом технічної системи.

2. Визначення глибини входження робочого електроду в грунт з використанням копіювального колеса.

3. Зменшення приросту площі на одиницю глибини/входження в грунт робочого електроду, обумовленого 
конструкцією трьохспицевого тонкостінного металевого диску 3 ободом у розробленій конструкції.

4. Відсутність утворення борозни робочими електродами внаслідок компенсації кута рискання верхніми та нижніми шарнірами підвіски кута $\alpha$.

Пристрій для визначення електропровідних властивостей грунтового середовища дає можливість оперативно визначити зони варіабельності агробіологічного стану грунтового середовища, забезпечити «індивідуальний» підхід до кожної елементарної ділянки поля 3 використанням даних електропровідних властивостей грунтового середовища та ідентифікувати їх подальшим лабораторним аналізом.

Таке технологічне рішення дасть можливість забезпечити оптимальне керування нормою висіву технологічного матеріалу (насіння, добрива тощо) із врахуванням агробіологічного стану грунтового середовища.

Метод розрахунку питомої електропровідності грунту $(\sigma)$ стаціонарним контактним методом. Спроектуємо еквіваленту розрахункову схеми інформаційно-технічної системи локального оперативного моніторинг агробіологічного стану сільськогосподарських угідь грунтового середовища (рис. 3).

Запишемо Закон Ома для повного ланцюга (замкненого):

$$
I=\frac{E_{\text {e.p.c. }}}{R_{\text {повне }}+r},
$$

де $E_{\text {e.p.c. }}$ - електрорушійна сила батареї живлення, В;

$R_{\text {повне }}-$ повний опір кола, Ом;

r - внутрішній опір батареї ,Ом. 


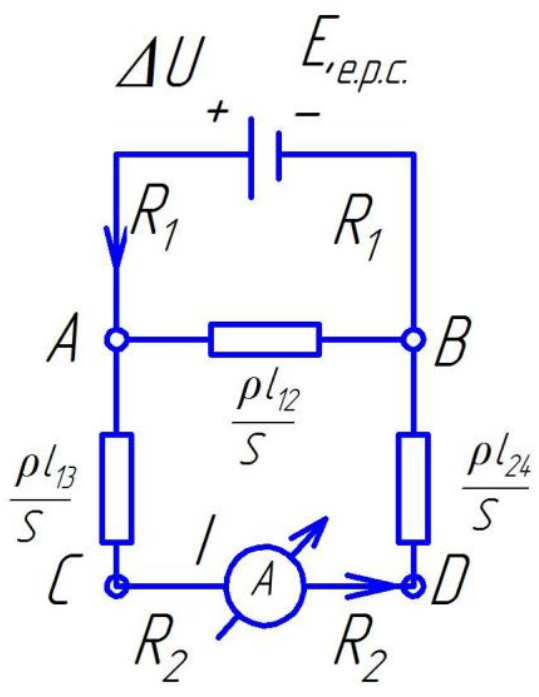

Рис. 6 - Еквівалентна розрахункову схеми інформаційно-технічної системи локального оперативного моніторинг агробіологічного стану сільськогосподарських угідь грунтового середовища.

Тоді

$$
I=\frac{E_{\text {e.p.c. }}}{R_{A B}+2 \cdot R_{1}+r},
$$

Повний опір кола буде визначатися за формулою:

$$
R_{A B}=\frac{\frac{\rho \cdot l_{12}}{S_{12}} \cdot\left(\frac{\rho \cdot l_{13}}{S_{13}}+\frac{\rho \cdot l_{24}}{S_{24}}+2 \cdot R_{2}+R_{A M \Pi}\right)}{\left(\frac{\rho \cdot l_{12}}{S_{12}}+\frac{\rho \cdot l_{13}}{S_{13}}+\frac{\rho \cdot l_{24}}{S_{24}}+2 \cdot R_{2}+R_{A M \Pi}\right)},
$$

Середньо арифметичні площі робочих контактів пристрою для визначення агробіологічних параметрів грунтового середовища, $\mathcal{M}^{2}$ : 


$$
S_{12}=\frac{S_{1}+S_{2}}{2}, S_{13}=\frac{S_{1}+S_{3}}{2}, S_{24}=\frac{S_{2}+S_{4}}{2}
$$

Середньо арифметичні площі робочих контактів пристрою для визначення агробіологічних параметрів грунтового середовища, $\mathcal{M}^{2}$ :

$$
S_{13}=\frac{S_{1}+S_{3}}{2}, S_{34}=\frac{S_{3}+S_{4}}{2} \quad S_{42}=\frac{S_{2}+S_{4}}{2}
$$

Тоді з виразу (1) будемо мати:

$$
R_{A B}+2 \cdot R_{1}+r=\frac{E_{e . p . c .}}{I} .
$$

Звідси

$$
R_{A B}=\frac{E_{\text {e.p.c. }}}{I}-2 \cdot R_{1}-r .
$$

Як вірно $R_{A M N}$ чи $R_{A M \Pi}$ ?

Для реальної ситуації $\left(2 \cdot R_{2}, R_{A M N}\right) \rightarrow 0$. У ідеальному амперметра $R_{A M N} \rightarrow 0,2 \cdot R_{2}$ - опір проводів, що підводять струм до пластин $S_{3}$ та $S_{4}$.

Тоді: 


$$
R_{A B}=\frac{\frac{\rho \cdot l_{12}}{S_{12}} \cdot\left(\frac{l_{13}}{S_{13}}+\frac{l_{24}}{S_{24}}\right)}{\left(\frac{l_{12}}{S_{12}}+\frac{l_{13}}{S_{13}}+\frac{l_{24}}{S_{24}}\right)} .
$$

Підставляємо (8) у (7) та отримуємо:

$$
\begin{aligned}
& \frac{\frac{\rho \cdot l_{12}}{S_{12}} \cdot\left(\frac{l_{13}}{S_{13}}+\frac{l_{24}}{S_{24}}\right)}{\left(\frac{l_{12}}{S_{12}}+\frac{l_{13}}{S_{13}}+\frac{l_{24}}{S_{24}}\right)}=\frac{E_{\text {e.p.c. }}}{I}-2 \cdot R_{1}-r, \\
& \delta=\frac{1}{\rho}=\frac{\frac{\rho \cdot l_{12}}{S_{12}} \cdot\left(\frac{l_{13}}{S_{13}}+\frac{l_{24}}{S_{24}}\right)}{\left(\frac{E_{\text {e.p.c. }}}{I}-2 \cdot R_{1}-r\right) \cdot\left(\frac{l_{12}}{S_{12}}+\frac{l_{13}}{S_{13}}+\frac{l_{24}}{S_{24}}\right)} .
\end{aligned}
$$

Остаточно:

$$
\delta=\frac{\frac{\rho \cdot l_{12}}{S_{12}} \cdot\left(\frac{l_{13}}{S_{13}}+\frac{l_{24}}{S_{24}}\right)}{\left(\frac{E_{\text {e.p.c. }}}{I}-2 \cdot R_{1}-r\right) \cdot\left(\frac{l_{12}}{S_{12}}+\frac{l_{13}}{S_{13}}+\frac{l_{24}}{S_{24}}\right)} .
$$

Точна формула для даного випадку буде: 


$$
\begin{aligned}
& \frac{\frac{\rho \cdot l_{12}}{S_{12}} \cdot\left(\frac{\rho \cdot l_{13}}{S_{13}}+\frac{\rho \cdot l_{24}}{S_{24}}+2 \cdot R_{2}+R_{A M \Pi}\right)}{\left(\frac{\rho \cdot l_{12}}{S_{12}}+\frac{\rho \cdot l_{13}}{S_{13}}+\frac{\rho \cdot l_{24}}{S_{24}}+2 \cdot R_{2}+R_{A M \Pi}\right)}=\frac{E_{\text {e.p.c. }}}{I}-2 \cdot R_{1}-r(12) \\
& \rho^{2} \cdot \frac{l_{12}}{S_{12}} \cdot\left(\frac{l_{13}}{S_{13}}+\frac{l_{24}}{S_{24}}\right)+\rho \cdot \frac{l_{12}}{S_{12}} \cdot\left(2 \cdot R_{2}+R_{A M I}\right)=\left(\frac{E_{\text {e.p.c. }}}{I}-2 \cdot R_{1}-r\right) . \\
& \cdot\left(2 \cdot R_{2}+R_{\text {AMI }}\right)+\left(\frac{E_{\text {e.p.c. }}}{I}-2 \cdot R_{1}-r\right) \cdot \rho \cdot\left(\frac{l_{12}}{S_{12}}+\frac{l_{13}}{S_{13}}+\frac{l_{24}}{S_{24}}\right)
\end{aligned}
$$

$\rho^{2} \cdot \frac{l_{12}}{S_{12}} \cdot\left(\frac{l_{13}}{S_{13}}+\frac{l_{24}}{S_{24}}\right)+\rho \cdot \frac{l_{12}}{S_{12}} \cdot\left(2 \cdot R_{2}+R_{A M \Pi}\right)-\left(\frac{E_{\text {e.p.c. }}}{I}-2 \cdot R_{1}-r\right)$.

$\cdot\left(2 \cdot R_{2}+R_{\text {AMI }}\right)-\left(\frac{E_{\text {e.p.c. }}}{I}-2 \cdot R_{1}-r\right) \cdot \rho \cdot\left(\frac{l_{12}}{S_{12}}+\frac{l_{13}}{S_{13}}+\frac{l_{24}}{S_{24}}\right)=0$

Введемо позначення:

$$
\left\{\begin{array}{c}
A_{1}=\frac{l_{12}}{S_{12}} \cdot\left(\frac{l_{13}}{S_{13}}+\frac{l_{24}}{S_{24}}\right) ; \\
A_{2}=\frac{l_{12}}{S_{12}} \cdot\left(2 \cdot R_{2}+R_{A M \Pi}\right)-\left(\frac{E_{\text {e.p.c. }}}{I}-2 \cdot R_{1}-r\right) \cdot\left(\frac{l_{12}}{S_{12}}+\frac{l_{13}}{S_{13}}+\frac{l_{24}}{S_{24}}\right) \\
A_{3}=\left(\frac{E_{\text {e.p.c. }}}{I}-2 \cdot R_{1}-r\right) \cdot\left(2 \cdot R_{2}+R_{A M \Pi}\right) .
\end{array}\right.
$$

Тоді маємо:

$$
\rho^{2} \cdot A_{1}+\rho \cdot A_{2}-A_{3}=0 ;
$$


Звідси

$$
\rho_{1,2}=\frac{-A_{2} \pm \sqrt{A_{2}^{2}+4 \cdot A_{1} \cdot A_{3}}}{2 \cdot A_{1}} .
$$

Оскільки, $\rho_{1} \succ 0, \rho_{2} \succ 0$, тоді корінь 3 мінусом перед радикалом не відповідає фізичному змісту величини $\rho$ :

$$
\rho=\frac{-A_{2} \pm \sqrt{A_{2}^{2}+4 \cdot A_{1} \cdot A_{3}}}{2 \cdot A_{1}} .
$$

Звідси остаточно маємо:

$$
\delta=\frac{1}{\rho}=\frac{2 \cdot A_{1}}{-A_{2} \pm \sqrt{A_{2}^{2}+4 \cdot A_{1} \cdot A_{3}}}
$$

Висновоки. Запропонована методика розрахунку питомої електропровідності агробіологічного грунтового середовища стаціонарним контактним методом робочих електродів інформаційно-технічної системи локального оперативного моніторингу дозволить отримання достовірних даних про стан грунтового середовища шляхом зменшення похибки при визначенні величини електропровідних властивостей грунту, забезпечення індивідуальної стабілізації робочих електродів та механізму піднімання/опускання робочих електродів, копіювання нерівностей грунтового середовища, зменшення інтенсивності руйнування структури грунту, самоочищення робочого контакту електроду i забезпечення стабільності електричного контакту електрода 3 грунтом, шляхом удосконалення конструкції приладу 3 використанням запропоновано методики.

Результатом використання пристрою для визначення електропровідних властивостей грунтового середовища конструкції $\epsilon$ отримання підвищення прибутку на $20-30 \%$ за рахунок оптимізації норми висіву технологічного матеріалу із врахуванням агробіологічного стану сільськогосподарських угідь. 


\section{Література:}

1. Адамчук В.В., Мойсеєнко В.К., Кравчук В.І., Войтюк Д.Г. Техніка для землеробства майбутнього. В зб.: Механізація та електрифікація сільського господарства. - Глеваха: ННЦ „ІМЕСГ”. 2002. Вип.86. С. 20-32.

2. Броварець О. Від безплужного до глобального розумного землеробства Броварець О. Техніка і технології АПК. 2016. № 10 (85). C. 28 - 30.

3. Броварець О.О. Інформаційно-технічна система оперативного моніторингу стану грунтового середовища конструкції Олександра Броварця. Вісник Львівського національного аграрного університету. Агроінженерні дослідження № 21. c. 9-29.

4. Вадюнина А.Ф. К оценке электропроводности как метода определения влажности почв. Почвоведение. 1937. № 3. С. 391-404.

5. Воробьев Н.И. К вопросу кондуктометрического определения засоленности почв и грунтов. Воробьев Н.И. Почвоведение. 1955. №4. С. 103.

6. ГОСТ 26423-85. Почвы. Методы определения удельной электрической проводимости, $\mathrm{pH}$ и плотного остатка водной вытяжки. 7c.

7. Гуков Я.С., Линник Н.К., Мироненко В.Г. Автоматизированная система локально-дозированного внесения удобрений, мелиорантов и средств защиты растений.: Труды 2-й МНПК по проблемам дифференциального применения удобрений в системе координатного земледелия. Рязань, 2001. С.48-50.

8. Копикова Л.П. Опыт применения методов электропроводности для составления детальных почвенномелиоративных карт. Копикова Л.П. Бюллетень ВИУА. 1979. №43. c. 21-23.

9. Масло І.П., Мироненко В.Г. Автоматизована система локально-дозованого внесення добрив і хімічних засобів захисту рослин. УААН: Розробки-виробництву. К.: Аграрна наука, 1999. C.348-349.

10. Медведев. В.В. Неоднородность почв и точное земледелие. Часть І. Введение в проблему. Харьков, 2007. - 296 с.

11. Ормаджи К.С. Контроль качества полевых работ. М.: Росагропромиздат. 1991. - 191с.

12. Сучасні тенденції розвитку конструкцій сільськогосподарської техніки. За ред. В.I. Кравчука, М.I. Грицишина, С.М. Коваля. К.: Аграрна наука, 2004. - 398 с. 
13. Oleksandr Brovarets, Yuriy Chovnyuk. Modeling and analysis of efficient electromagnetic parameters of capillary system of electrical conductivity of agricultural soils i: method of analysis of non-stationary electromagnetic fields in dispersive and controlled environments. MOTROL. Vol. 19, 2018. No 4. p. 13- 18.

14. Oleksandr Brovarets, Yuriy Chovnyuk. Technical - economic models of business management in the processes of agricultural production. ECONTECHMOD. An international quarterly journal.2017. Vol. 6. No. 3, 61-70.

15. Oleksandr Brovarets, Yuriy Chovnyuk. Integrated systems of management for the performance of technological processes in agricultural production which depend on the initial and final moments of their operation time. Teka. 2017.Vol. 17, No 2. p. 79 - 90.

16. Oleksandr Brovarets. Organizational and Technological Background of Project Configuration Management for Freighting. Teka. Vol. 17, 2017. No 3. p. 49 - 53.

17. Hertz A. Chad and John D. Hibbard. A Preliminary Assessment of the Economics of Variable Rate Technology for Applying Phosphorus and Potassium in Corn Production. Farm Economics iss. 14, Department of Agricultural Economics, University of Illinois, Champaign-Urbana. 1993. P. 218-231.

18. Wilcox G.G. Determination of electrical conductivity of soil solutions. Soil Science. 1947. v. 63. p. 107.

19. Ewart G.Y., Baver L.D. Salinity Effects on soil moisture electrical resistance relstionships. Soil Scien. Soc. Amer. 1950. v. 15. pp. 56-63.

20. Rhoades J.D., Schifgaarde J. Van. Soil Scien. Soc. Amer. J.An electrical conductivity probe for determining soil salinity. 1976. № 5. pp. 647-651. 